\title{
金属粉末の静水圧下圧密構成式の検討
}

\author{
王雨勃松木一弘柳沢平 \\ 広島大学大学院工学研究科 \\ J. Japan Inst. Metals, Vol. 66, No. 4 (2002), pp. 393-399 \\ (C) 2002 The Japan Institute of Metals
}

\section{Constitutive Equation for Cold Isostatic Compaction of Metal Powders}

Yubo Wang, Kazuhiro Matsugi and Osamu Yanagisawa

Graduate School of Engineering, Hiroshima University, Higashi-Hiroshima 739-8527

For application of "particle contact theory" proposed by several investigators for compaction using mono-sized spherical powder particles to that for powders of general shape and of general size distribution, metallographical method was carried out to obtain the constitutive equation for isostatic compaction of metallic powders. Comparing the obtained equation with experimental results, the approximated constitutive equation to represent the isostatic pressure, $P$, to densify powder aggregate from the initial relative density, $D_{0}$, to the achieved relative density, $D$, is finally conducted as $P=(3 / 4) \sigma_{\mathrm{eq}}\left(D / D_{0}\right)^{1 / 3}\left(D-D_{0}\right) /(1-D)$

where $\sigma_{\text {eq }}$ is equivalent stress at the contact surface having the value close to $0.2 \%$ proof yield stress of powder material. By mixing a lubricant in powder aggregate, the isostatic pressure to obtain the same relative density is smaller compared with that represented by the above equation.

(Received November 19, 2001; Accepted February 8, 2002)

Keywords: metal powder, isostatic pressure, compaction, constitutive equation

\section{1. 緒言}

金属粉末の圧密構成式は古くから検討され，種々の実験式 が提唱されている1). Fischmeister の静水圧下圧密に打引 等粒径球形粒子の接触面積の測定と計算 ${ }^{2,3}$ 以降, ミク口的 な粒子の接触面積と接触圧力からマクロ的な相対密度と外力 の関係を導く方法 $\left.{ }^{4-6}\right)$ が検討されてきた(「粒子接触理論」と 呼ぶ). この方法は一般的な 3 軸応力場への拡張まで試みら れている7,8) が, 等粒径球形粒子の粒子接触の理論から誘導 された計算式が一般形状の非等粒径粒子に対しても適用でき るという暗黙の仮定を前提としている.

また Mises 型の降伏条件式を圧密過程に適用するため, 古くからこの式の形と係数の相対密度依存性が多く提案され ているが9-13)(「Mises 型降伏理論」と呼ぶ)，これらは必ず しも上記のアプローチと結びついていない.

上記「粒子接触理論」と「Mises 型降伏理論」の両者を直 接的に比較できるのは, 部分的ではあるが静水圧下圧密であ る. しかし両者の関係をみても必ずしもよい一致はみられな い. そこで, 本研究では従来の等粒径球形粒子に対して求め られた粒子接触理論が, 一般粒子形状の非等粒径粒子でも適 用できるような金属組織学的なアプローチを試み, 得られた 結論と実験結果の比較を試みた.

\section{2. 実 験 方 法}

4 種類の純銅粉, 純アルミニウム粉および 3 種類の 7075 アルミニウム合金粉を実験に供した７075 アルミニウム合 金粉の化学組成を Table 1, 全ての粒子の大きさ执よ゙゙みか け密度を Table 2 に示す. 7075 合金粉の場合, 同じアトマ イズ粉を篩分けして 3 種類の粉末サイズとした。これらの 走査電子顕微鏡 $(\mathrm{SEM})$ 像を Fig. 1 に示す. $\phi 17.5 \mathrm{~mm} \times \mathrm{L} 32$ $\mathrm{mm}$ のシリコンゴム・カプセルの中に粉末を詰め, 冷間静水 圧縮 $(\mathrm{CIP})$ した，等粒径銅粉の場合，上記の方法で圧密する ことが出来なかったので，放電焼結機を利用して，約 $10^{-2}$ $\operatorname{Torr}(10 \mathrm{~Pa})$ の真空中で無加圧で予備焼結を行った. $300 \mathrm{~s}$ 間で $1173 \mathrm{~K}$ まで昇温し， $300 \mathrm{~s}$ 保持した後 $323 \mathrm{~K}$ までを $1200 \mathrm{~s}$ かけて冷却した。予備焼結後の相対密度は 0.64 であ った。

粉末粒子相互の滑りが圧密に必要な圧力におよぼす影響を 調べるために, 各種銅粉に液体パラフィンを $1.0 \mathrm{vol} \%$ 添加 して，同様の方法で冷間静水圧縮した。この時のみかけ密度 をTable 2 の括弧中に示した.

静水圧縮後の圧粉体の表面をアクリル・スプレーでコーテ イングし, 密度測定に供した. 真密度材料の測定によって, このコーテイングでもたらされる測定誤差は, 銅の場合 0.5\%, アルミニウムの場合 $1 \%$ であった. 
Table 1 Compositions of $7075 \mathrm{Al}-\mathrm{Zn}-\mathrm{Mg}-\mathrm{Cu}$ alloy (mass\%).

\begin{tabular}{|c|c|c|c|c|c|c|c|c|c|c|c|}
\hline \multirow{2}{*}{$\mathrm{Si}$} & \multirow{2}{*}{$\mathrm{Fe}$} & \multirow{2}{*}{$\mathrm{Cu}$} & \multirow{2}{*}{$\mathrm{Mn}$} & \multirow{2}{*}{$\mathrm{Mg}$} & \multirow{2}{*}{$\mathrm{Cr}$} & \multirow{2}{*}{$\mathrm{Zn}$} & \multirow{2}{*}{$\mathrm{Ti}$} & \multirow{2}{*}{$\mathrm{Zr}+\mathrm{Ti}$} & \multicolumn{2}{|c|}{ Other } & \multirow{2}{*}{$\mathrm{Al}$} \\
\hline & & & & & & & & & each & total & \\
\hline$<0.4$ & $<0.5$ & $1.2 \sim 2.0$ & $<0.3$ & $2.1 \sim 2.9$ & $0.18 \sim 0.28$ & $5.1 \sim 6.1$ & $<0.2$ & $<0.25$ & $<0.05$ & $<0.15$ & bal. \\
\hline
\end{tabular}

Table 2 Particle size and apparent density.

\begin{tabular}{lllc}
\hline \multicolumn{1}{c}{ Kind of powder } & $\begin{array}{c}\text { Symbol in } \\
\text { this paper }\end{array}$ & $\begin{array}{c}\text { Particles size } \\
\left(m \times 10^{-6}\right)\end{array}$ & $D_{0}$ \\
\hline Fine electrolytic $\mathrm{Cu}$ & $\mathrm{FECu}$ & $<50$ & $\begin{array}{c}0.18 \\
(0.17)\end{array}$ \\
\hline Coarse electrolytic $\mathrm{Cu}$ & $\mathrm{CECu}$ & $45 \sim 180$ & $\begin{array}{c}0.24 \\
(0.29)\end{array}$ \\
\hline Water atomized $\mathrm{Cu}$ & $\mathrm{ATCu}$ & $<45$ & $\begin{array}{c}0.39 \\
(0.27)\end{array}$ \\
\hline Mono-size spherical Cu & SPCu & $180 \sim 250$ & 0.58 \\
\hline Fine 7075 alloy Al & $7075 \mathrm{~F}$ & $<45$ & 0.34 \\
\hline Middle 7075 alloy Al & $7075 \mathrm{M}$ & $45 \sim 180$ & 0.36 \\
\hline Coarse 7075 alloy Al & $7075 \mathrm{C}$ & $180 \sim 300$ & 0.38 \\
\hline Atomized pure Al & pure Al & $45 \sim 180$ & 0.42 \\
\hline
\end{tabular}

( $D_{0}$ in bracket: with liquid paraffin as a lubricant)

\section{3. 塑性変形による圧密における幾何学的関係}

\section{1 モデル}

Fig. 2 に示すように粉末粒子集合体の圧粉を(a)粒子間の 接近，(b)粒子のオーバーラップおよび (c) オーバーラップ 部の体積の空洞部への移動の 3 過程からなると考える。初 期空洞部 (体積率 : $1-D_{0}$ ) に対して KJMA ${ }^{14}$ ) (KolmogorovJohnson-Mehl-Avrami)式を適用すると式 (1)が得られる.

$$
(1-D) /\left(1-D_{0}\right)=\exp \left\{-\delta_{\mathrm{ex}} /\left(1-D_{0}\right)\right\}
$$

ここで古くから相変態の問題で，变態相の体積率を計算する 方法として用いられている KJMA 式は，オーバーラップを 許した析出相の体積率を $V_{\mathrm{ex}}$ とした時, 実体積率 $V$ が式 (2)で表されるというもので, 式 (1) は単位体積中の初期 空隙 $\left(1-D_{0}\right)$ のみに着目して, 上記 $(\mathrm{a}),(\mathrm{b})$ と (c)の過程で オーバーラップを許して初期空隙を部分的に埋めた拡張体積 率(単位体積を基準)を $\delta_{\mathrm{ex}}$ としている(Fig. 3).

$$
V=1-\exp \left(-V_{\mathrm{ex}}\right)
$$

式(1)を $\delta_{\text {ex }}$ で微分すると式 $(3)$ が得られる.

$$
d D / d \delta_{\mathrm{ex}}=(1-D) /\left(1-D_{0}\right)
$$

圧粉過程を上記のような 3 過程からなると考えれば，粒 子間の接近によって自由表面が空隙内部に移動し, これによ ってまず空隙部の体積が減少し, さらにオーバーラップ部の 体積が空隙部の一部を埋めることによって相対密度が増加す ると考えられる。粒子間の微小圧縮変位を $d l$, 粒子 1 個あ たりの接触面積を $\Sigma a$ とし, 圧縮体積 $\Sigma a d l$ と $d D$ あるいは $d \delta_{\mathrm{ex}}$ との関係がわかれば，式（3）を用いて $\Sigma a d l$ と相対密度 との関係を求めることができる. 考えている 1 つの粒子の 体積を $v_{0}$ とすれば Volonoi cell 体積 ${ }^{5}$ は $\left(v_{0} / D\right)$ であるから， 圧縮率増分は $\Sigma a d l /\left(v_{0} / D\right)$ と表される。圧密開始において は, 粒子接触面積にくらべて自由表面面積が非常に大きいの で， $d D$ や $d \delta_{\mathrm{ex}}$ は自由表面の移動だけで決定されるが，圧密
が進むと $d D$ や $d \delta_{\mathrm{ex}}$ が自由表面の移動だけではなく圧縮率 増分の影響が強くなる. しかしその関数関係は幾何学的関係 からだけでは直ちには求まらない。いま, 圧縮率増分がオ一 バーラップ体積の増分 $\left(d \delta_{\mathrm{ex}}-d D\right)$ に比例するとすれば，比 例定数 $k$ を用いて式 $(4)$ が成立する.

$$
\Sigma a d l /\left(v_{0} / D\right)=k\left(d \delta_{\mathrm{ex}}-d D\right)
$$

自由表面面積 $s_{\mathrm{f}}$ と接触面面積 $s_{\mathrm{c}}$ の和を $s$ として, $\Sigma a / s(=$ $A$ )は式（４）を用いて式（5)のように表される.

$$
A=\Sigma a / s=k\left(v_{0} / s_{0}\right)\left\{\left(d \delta_{\mathrm{ex}} / d D\right)-1\right\}(1 / D)(d D / d l)
$$
変形をしていない初期粒子の平均カリパス径を $l_{0}$, 粒子接触 面の法線方向のカリパス径を $l$ とすれば, 静水圧縮の場合に は $l / l_{0}=\left(D_{0} / D\right)^{1 / 3}$ であるから, 式 $(6)$ が成立する.

$$
d l=(1 / 3) D_{0}^{1 / 3} l_{0} D^{-4 / 3} \mathrm{~d} D
$$

式 (3), および式 (6)を用いて, 式 ( 5 )は式 ( 7 )のように 整理される。

$$
A=3 k\left(v_{0} / s_{0} l_{0}\right)\left(D / D_{0}\right)^{1 / 3}\left(D-D_{0}\right) /(1-D)
$$

上式において， $D$ が 1 に近づくと $A$ は無限大の值をとる. これは式 (1)の仮定からくるものである.Arzt らの粒子接 触理論による接触面積率4) を繰り返し計算によって厳密に求 めると式 $(7)$ と同様に， D が 1 に近づくと無限大の值にな る.

\section{2 実接触面積}

いま式 ( 7 ) で表される 1 つの粒子表面積中の接触面積率 $A$ が Fig. 4 に示すように接触面の接触と交差を許した拡張 面積率と考えれば, 再び KJMA 式を用いて, 実接触面積率 $A_{\mathrm{t}}\left(A_{\mathrm{t}}=\Sigma a_{\mathrm{t}} / s, a_{\mathrm{t}}\right.$ : 実接触面積) は式 $(7)$ を用いて式 $(8)$ のよ うに表される。

$$
\begin{aligned}
A_{\mathrm{t}} & =1-\exp (-A) \\
& =1-\exp \left[-3 k\left\{v_{0} /\left(s_{0} l_{0}\right)\right\}\left(D / D_{0}\right)^{1 / 3}\left(D-D_{0}\right) /(1-D)\right]
\end{aligned}
$$

\section{$3.3 v_{0} /\left(s_{0} l_{0}\right)$ の値}

式 ( 7 ) と式 ( 8 ) 中の $v_{0} /\left(s_{0} l_{0}\right)$ の值は粉末粒子の形状に依 存する. 圧密前の変形していない球形粉末粒子の場合, 粒子 表面積 $s$ を $s_{0}$ に置き換えると $v_{0}=\pi l_{0}^{3} / 6, s_{0}=\pi l_{0}^{2}$ であるから $v_{0} /\left(s_{0} l_{0}\right)=1 / 6$ である. 長さ $l_{\mathrm{c}}$, 半径 $r$ の円柱の両端に直径 $l_{\mathrm{c}}$ の半球を持った粒子を原点のまわりに 3 次元的に回転させ, $x$ 軸方向のカリパス径を計って平均すると, 平均カリパス径 $l_{0}$ は式 ( 9 )で表される.

$$
l_{0}=l_{\mathrm{c}} / 2+2 r
$$

これを用いて粒子のアスペクト比の関数として $v_{0} /\left(s_{0} l_{0}\right)$ を 表すと Fig. 5 が得られた. 本図からもわかるように, アス ペクト比が 1 のとき $\left(v_{0} / s_{0} l_{0}\right)$ の值は 0.166 であるが，アスペ クト比が 3 程度にまで大きくなると, $v_{0} /\left(s_{0} l_{0}\right)$ の值は約 0.133 (約 $16 \%$ の変化) まで小さくなる. しかしこの影響があ 


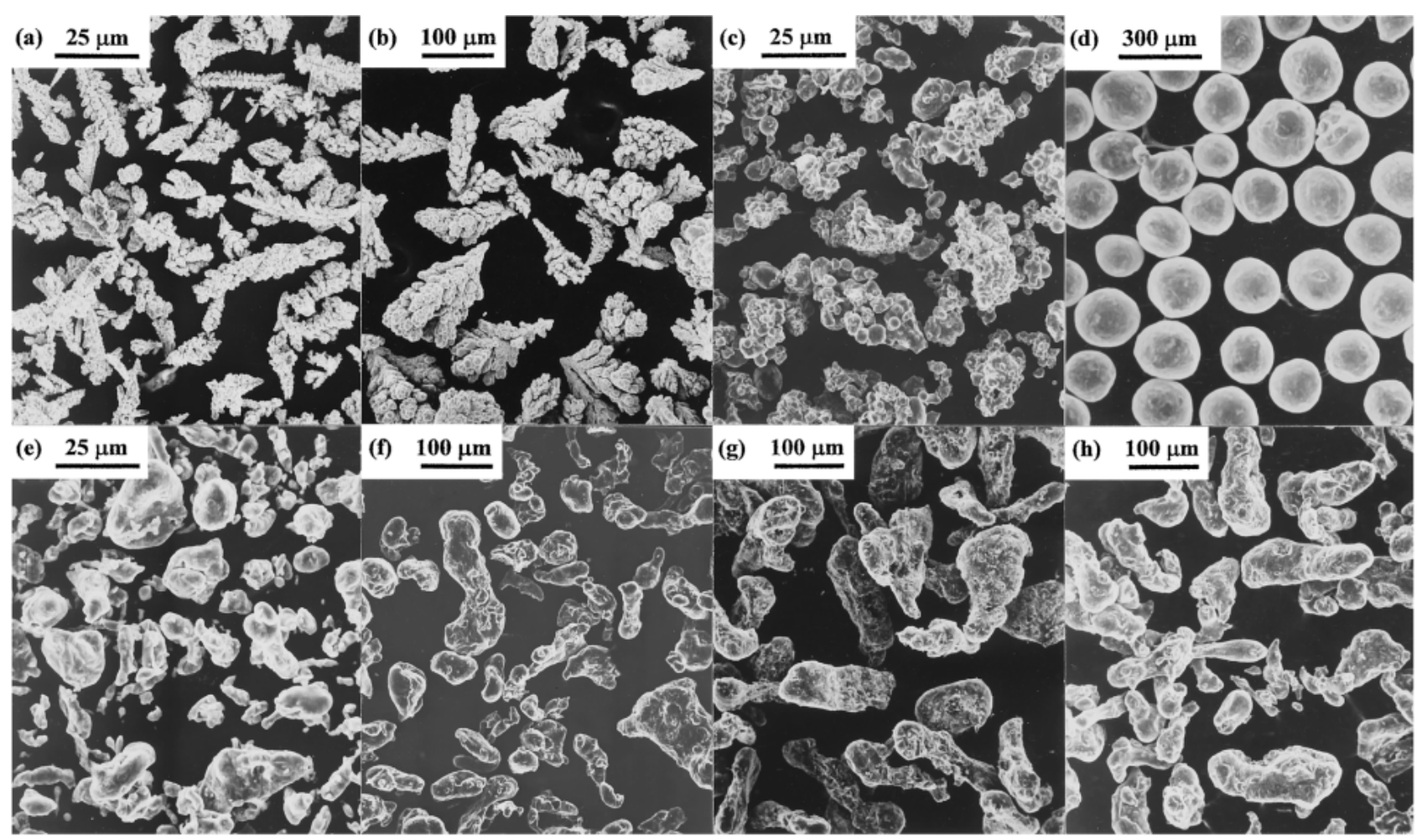

Fig. 1 SEM image of powders showing (a) FECu, (b) CECu, (c) ATCu, (d) SPCu, (e) F7075, (f) M7075, (g) C7075 and (h) Pure $\mathrm{Al}$.

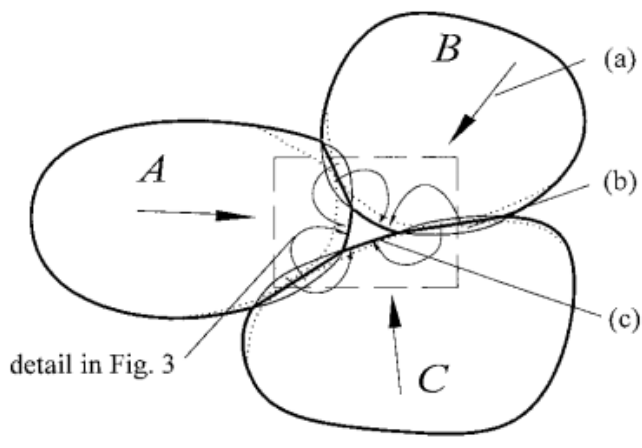

Fig. 2 Schematic drawing of compaction of plastic powder under isostatic pressure condition by three processes, (a) powder approaching, (b) overlapping, (c) filling the overlapped part in void space.

ったとしても，特に圧密がある程度進んだ段階でそれほど大 きいものとは考えられない.

\section{4 静水圧下圧密関数}

Molerus ${ }^{15)}$ によって提唱され，Fischmeister と Arzt ${ }^{3)}$, Larsson $5^{6)}$ によって使用されてきた面積比 $A$ と接触面に働 く垂直応力 $\sigma_{\mathrm{n}}$ の関係は式(10)で表される.

$$
s P=D \Sigma a \sigma_{\mathrm{n}} \Longrightarrow P=D A \sigma_{\mathrm{n}}
$$

ここで $\sigma_{\mathrm{n}}$ として, Fischmeister ら ${ }^{3)}$, Arzt $^{4)}$, Helle $^{5)}$ によ って使われた $\sigma_{\mathrm{n}}=3 \sigma_{\mathrm{eq}}\left(\sigma_{\mathrm{eq}}\right.$ は粉末材料の相当応力あるいは 降伏応力)の関係を用いている. 式 ( 7 ) と式 (10)を用いて $P$ を表すと式(11)が得られる.

$$
P=9 k D \sigma_{\text {eq }}\left(v_{0} / s_{0} l_{0}\right)\left(D / D_{0}\right)^{1 / 3}\left(D-D_{0}\right) /(1-D)
$$

式 $(11)$ に扔いて，接触面積率として実面積率 $A_{\mathrm{t}}$ を使わず

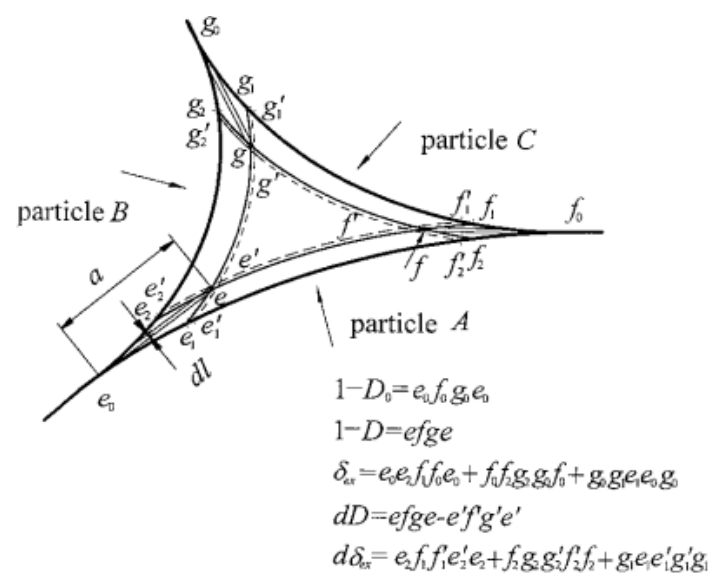

Fig. 3 Geometric relation in the initial void space, $\delta_{\text {ex }}$ is extended volume fraction, $(1-D)$ is void fraction at $D ; d D, d \delta_{\text {ex }}$ and $d l$ are increments of relative density, extended relative density and compressive displacement at contact surface respectively.

に拡張面積率 $A$ を使っているので， $D$ が 1 に近づくと $P$ は 無限大の值になる.

\section{4. 実験結果との比較}

\section{1 等粒径球形銅粉末}

Fig. 6(a)に本実験で得られた全ての銅粉末，同図(b)に純 アルミニウム粉末抢よびアルミニウム合金粉末の相対密度 $D$ と圧力 $P$ との関係を示す.

塑性変形する等粒径球形粒子粉末を静水圧縮して相対密度 


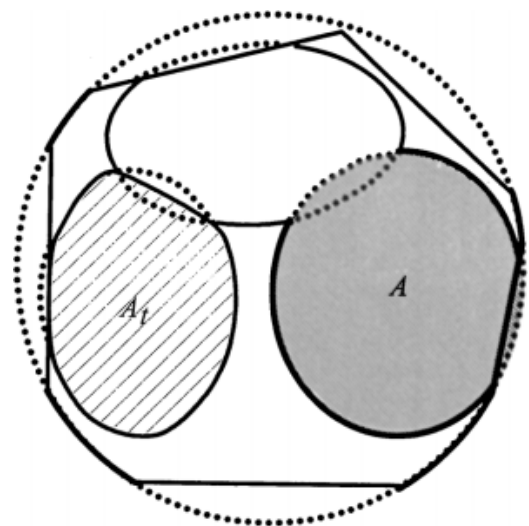

Fig. 4 True contact area, $A_{\mathrm{t}}$, and extended contact area, $A$.

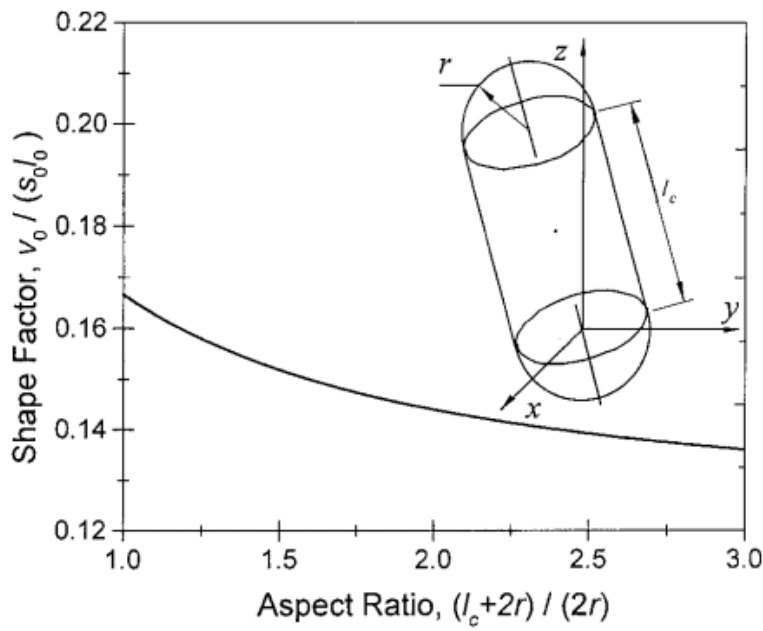

Fig. 5 Variation of shape factor, $v_{0} /\left(s_{0} l_{0}\right)$, due to the change of aspect ratio, $(l+2 r) /(2 r)$.

1 に近い值まで圧密したとすれば粒子形状はほぼテトラカイ デカヘドロンになると考えられている4)，この場合のテトラ カイデカヘドロンの表面積は圧密前の初期粒子表面積 $s_{0}$ の 約 1.1 倍程度と計算されるので ${ }^{16)}, s\left(s=s_{\mathrm{f}}+s_{\mathrm{c}} s_{\mathrm{f}}\right.$ : 自由表面 面積, $s_{\mathrm{c}}$ : 接触面面積 $)$ を $s_{0}$ として $A, A_{\mathrm{t}}$ あるいは $P$ を計算 したとしても，影響は無視できる程度に小さい，いま $s か ゙$ 近 似的に $s_{0}$ に等しいとすれば，等粒径球形粉末粒子の場合， $v_{0}=\pi l_{0}^{3} / 6, s_{0}=\pi l_{0}^{2}$ であるから $v_{0} /\left(s_{0} l_{0}\right)=1 / 6$ となり，式 (7)，式(8)と式(11)はそれぞれ式(12)，式(13) と式(14) に書き変えられる。また $A$ の代わりに $A_{\mathrm{t}}($ 式(13))を用いた 場合の圧力を $P_{\mathrm{t}}$ とすれば式(15)が得られる.

$A=(k / 2)\left(D / D_{0}\right)^{1 / 3}\left(D-D_{0}\right) /(1-D)$

$A_{\mathrm{t}}=1-\exp (-A)$

$=1-\exp \left\{-(k / 2)\left(D / D_{0}\right)^{1 / 3}\left(D-D_{0}\right) /(1-D)\right\}$

$P=(3 k / 2) \sigma_{\text {eq }} D\left(D / D_{0}\right)^{1 / 3}\left(D-D_{0}\right) /(1-D)$

$P_{\mathrm{t}}=3 \sigma_{\mathrm{eq}} D\left[1-\exp \left\{-(k / 2)\left(D / D_{0}\right)^{1 / 3}\left(D-D_{0}\right) /(1-D)\right\}\right]$

Fig. 6 (a) 中の等粒径銅粉の実験結果は James の実験結 果17) とよく一致した． $k=1$ として横軸に $D[1-\exp \{-(1 /$ 2) $\left.\left.\left(D / D_{0}\right)^{1 / 3}\left(D-D_{0}\right) /(1-D)\right\}\right]$ を縦軸に実験による $P$ をと って整理すると Fig. 7 (a) が得られた。また横軸に $D(D /$

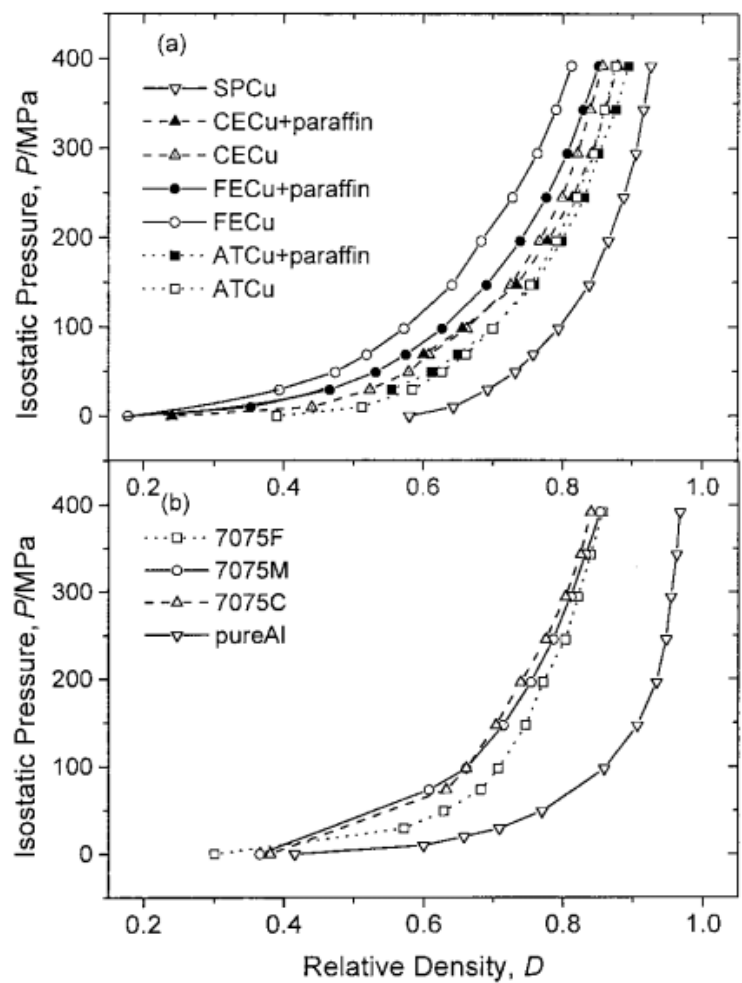

Fig. 6 Experimental results of isostatic pressure, $P$, to obtain relative density, $D$, for (a) pure $\mathrm{Cu}$ and (b) pure $\mathrm{Al}$ and 7075 aluminum alloy.

$\left.D_{0}\right)^{1 / 3}\left(D-D_{0}\right) /(1-D)$ を，綎軸に実験による $P$ をとって整 理すると Fig. 7 (b)が得られた。

Fig. 7 (a) に抢いて圧密初期の勾配 ( $3 \sigma_{\text {eq }}$ に相当する) は約 308 であり， $\sigma_{\text {eq }}$ の值は $103 \mathrm{MPa}$ と計算される。これは同じ 粉末加放電焼結 (黒鉛型内単軸圧縮 : $1273 \mathrm{~K}, 10 \mathrm{MPa}$, $300 \mathrm{~s}$ ) によって作製した焼結体(相対密度：0.999 以上)の引 張り試験結果から求めた $0.2 \%$ 耐力の值 $(100 \sim 110 \mathrm{MPa})$ と ほほ一致する。しかしこの場合, 圧密が進むに従って勾配は 大きくなって直線からずれる.

Fig. 7 (b)に抢いて圧密初期の段階の勾配 ( $(3 k / 2) \sigma_{\text {eq }}$ に相 当する)は約 130 で，圧密が進むに従って勾配は小さくなる ことが認められる。これは本実験に供した全ての粉末で認め られた傾向である.

式(14)中の $k$ は $D=D_{0}$ に打いて 1 に近い值で, 相対密度 が大きくなるに従って小さくなると考えられるので， $k$ を $D$ の関数として式(16)のように仮定すると式(14)は式(14-1) のように書き換えられる.

$k=k^{\prime}\left(D_{0} / D\right)$

$P=\left(3 k^{\prime} / 2\right) \sigma_{\text {eq }} D_{0}\left(D / D_{0}\right)^{1 / 3}\left(D-D_{0}\right) /(1-D)$

式(14-1)に従って横軸に $\left(D / D_{0}\right)^{1 / 3}\left(D-D_{0}\right) /(1-D)$ を, 綎軸に実験結果の $P$ をとって整理すると Fig. $8(\mathrm{a})$ が得られ た。これは非常によい直線関係を示し, この勾配と $\sigma_{\mathrm{eq}}=$ $105 \mathrm{MPa}$ 抢よび $D_{0}=0.58$ を使って $k^{\prime}$ を求めると 0.84 が得 られた。

式(11)，(14)あるいは(14-1)に扔いて，Dが 1 に近づくと, $P$ は無限大になる。実際の圧密の場合, 相対密度が大きくな ると，粒子接触部同士が粒子表面上で接触し始め，接触面の 

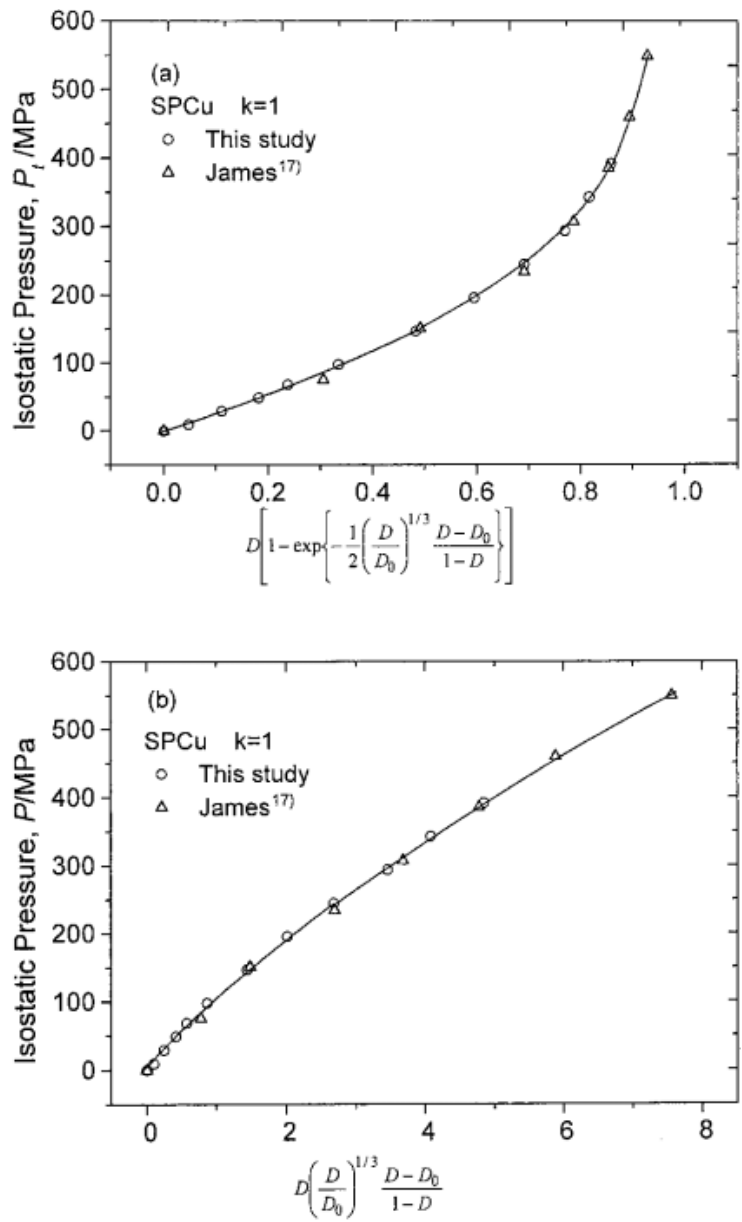

Fig. 7 Relation between isostatic pressure by experiment, $P$ and the functions of relative density, $D$, in (a) equation (15) and (b) equation (14-1).
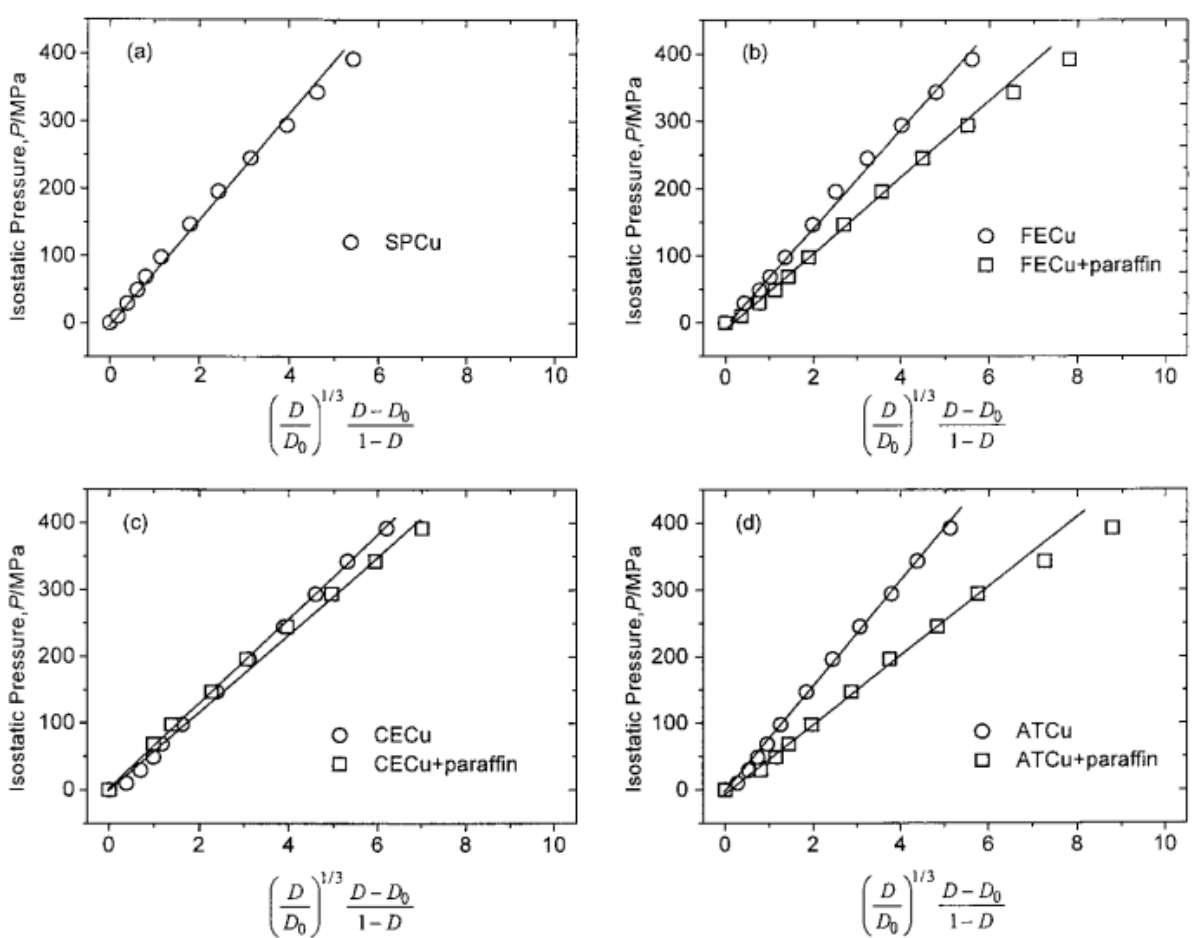

Fig. 8 The linear relation in equation (14-1) using some copper powders, (a) SPCu, (b) FECu and FECu + paraffin, (c) CECu and $\mathrm{CECu}+$ paraffin, (d) ATCu and $\mathrm{ATCu}+$ paraffin.

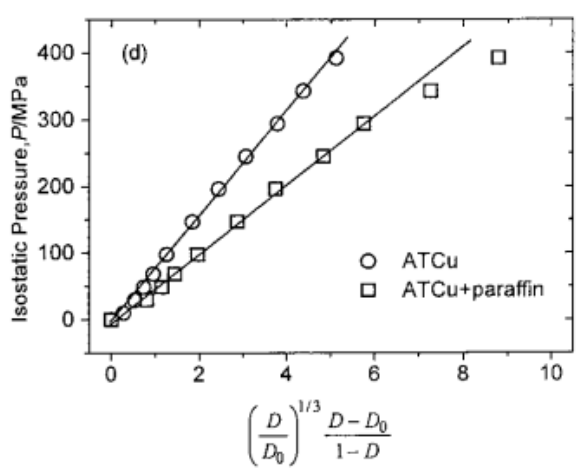

横方向压縮応力が増加し，静水压応力が増加する ${ }^{3)}$ ，そのた めに $D$ が 1 に近づくに従って圧力 $P$ が急激に増加する. 式 (11), (14) あるいは (14-1)の意味は $P$ の実際の変化の理由 とは異なるが，圧密後期においても，これらの式が実際の $P$ の変化を表すと仮定する.

\section{2 非等粒径非球形粉末}

一般の金属・合金粉末(非等粒径非球形)の例として，各種 純銅粉の静水圧縮に抢ける実験結果と式(14-1)の比較を Fig. 8(b)〜(d)に示す. ここで，純銅粉末材料の圧粉時にお ける接触面の相当応力がほぼ等しいとして, Fig. 8 の勾配 $k^{\prime}$ の值を求めると Table 3 が得られた. 電解銅粉とアトマイ ズ粉の $k^{\prime}$ の值は等粒径球形銅粉のそれよりも大きい值にな っている．また $D_{0}$ が小さいほど $k^{\prime}$ の值は大きな值になる. その結果, 初期相対密度 $D_{0}$ がどのような值であっても, $k^{\prime} D_{0}$ は $1 / 2$ に近い值になっている. そこで, $k^{\prime} D_{0} \fallingdotseq 1 / 2$ と すれば式(14-1) は近似式(14-2) と書き改められる.

$$
P=(3 / 4) \sigma_{\mathrm{eq}}\left(D / D_{0}\right)^{1 / 3}\left(D-D_{0}\right) /(1-D)
$$

式(14-2)は Morerus ${ }^{15)}$ による式(10)の代わりに，接触部 にかかる圧力の総和が粒子表面全体に外力(静水圧力)がかか るのと等価とした式(17)を用いた場合に相当する.

$$
s P=\Sigma a \sigma_{\mathrm{n}} \Longrightarrow P=A \sigma_{\mathrm{n}}=3 A \sigma_{\mathrm{eq}}
$$

従来の粒子接触理論で代表的な Helle $5^{5)}$ の式と比較する ために，再び等粒径球形粒子について，式(14-2) 抢よび実 表面積を用いた式 (15)による計算例と実験結果の比較を Fig. 9 に示す．相対密度が 0.85 以下ではどの式を用いても 結果は変わらず実験結果とよく一致する. 式(15) と Helle ら の式を比較してもそれらの結果にそれほど大きな違いはな く, 相対密度が 0.85 以上では両者ともに実験結果とは一致 
Table 3 Parameters in equation (14-1).

\begin{tabular}{|c|c|c|c|c|c|c|}
\hline & $D_{0}$ & $\begin{array}{c}1.5 k^{\prime} D_{0} \sigma_{\text {eq }} \\
\mathrm{MPa}\end{array}$ & $k^{\prime} D_{0}$ & $k^{\prime}$ & $\sigma_{\mathrm{eq}} \mathrm{MPa}$ & $\sigma_{0.2} \mathrm{MPa}$ \\
\hline $\mathrm{FECu}$ & $\begin{array}{l}0.18 \\
(0.17)\end{array}$ & $\begin{array}{c}72 \\
(53)\end{array}$ & $\begin{array}{l}0.46 \\
(0.34)\end{array}$ & $\begin{array}{c}2.60 \\
(2.06)\end{array}$ & $105^{*}$ & \multirow{4}{*}{$100 \sim \underset{110^{* *}}{\sim}$} \\
\hline $\mathrm{CECu}$ & $\begin{array}{l}0.24 \\
(0.29)\end{array}$ & $\begin{array}{c}66 \\
(55)\end{array}$ & $\begin{array}{c}0.42 \\
(0.35)\end{array}$ & $\begin{array}{l}1.79 \\
(1.27)\end{array}$ & $105^{*}$ & \\
\hline $\mathrm{ATCu}$ & $\begin{array}{l}0.39 \\
(0.27)\end{array}$ & $\begin{array}{c}79 \\
(47)\end{array}$ & $\begin{array}{c}0.51 \\
(0.30)\end{array}$ & $\begin{array}{l}1.31 \\
(1.14)\end{array}$ & $105^{*}$ & \\
\hline $\mathrm{SPCu}$ & 0.58 & 73 & 0.47 & 0.84 & $105^{*}$ & \\
\hline $7075 \mathrm{~F}$ & 0.34 & 101 & $0.5^{*}$ & & 134 & \multirow{3}{*}{$120^{* *}$} \\
\hline $7075 \mathrm{M}$ & 0.36 & 89 & $0.5^{*}$ & & 120 & \\
\hline $7075 \mathrm{C}$ & 0.38 & 106 & $0.5^{*}$ & & 140 & \\
\hline Pure Al & 0.42 & 18 & $0.5^{*}$ & & 23 & $\geq 20^{20)}$ \\
\hline $\begin{array}{l}\text { Pure } \\
\mathrm{Fe}^{177 \dagger}\end{array}$ & 0.38 & 107 & $0.5^{*}$ & & 143 & \\
\hline $\begin{array}{l}\text { Pure } \\
\mathrm{Ni}^{17) \uparrow}\end{array}$ & 0.49 & 242 & $0.5^{*}$ & & 322 & \\
\hline $\begin{array}{l}\text { Stainless } \\
\text { steel }^{17) \dagger}\end{array}$ & 0.29 & 175 & $0.5^{*}$ & & 233 & \\
\hline
\end{tabular}

Values in bracket: with liquid paraffin as a lubricant.

*: assumed

**: measured

†: referred

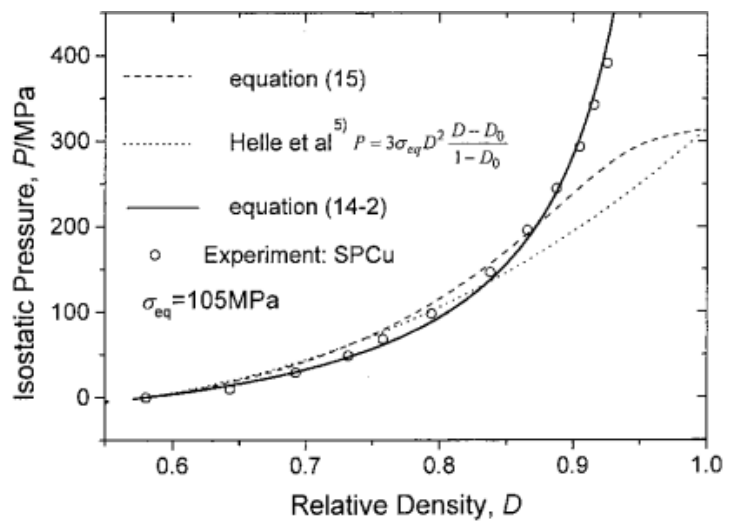

Fig. 9 Comparing the experimental result with the functions of the particles contact theory.

しない。これに対して式(14-2) は実験結果とよく一致して いる.

液体パラフィンを $1.0 \mathrm{vol} \%$ 添加して，粒子間の潤滑を促 した場合の結果を Fig. 8 と Table 3 に併せてに示してい る.アトマイズ粉の $k^{\prime} D_{0}$ の值は粒子間の摩擦を軽減するこ とによって 0.5 から 0.3 に低下した。 また，粗い電解銅粉の 場合で 0.42 から 0.35 に, 細かい電解銅粉の場合で 0.46 か ら 0.34 に低下した。いずれの場合も，液体パラフィンの 1.0 vol\% 添加によって $k^{\prime} D_{0}$ の值は小さい值になっている. 潤滑剂の添加によって，あまり大きな塑性変形を伴わずに再 配列18) が進み，これによって相対密度の増加が起こるの で，粒子接触面積が余り広がらないで圧密が可能になるもの と考えられる. $k^{\prime} D_{0}$ はこの影響を受けて小さくなったと推 察される.すなわち， $k^{\prime} D_{0}$ の值はパラフィンを添加しない 場合より小さくなり，0.6 0.8 倍の值になっている．以上の 結果より， $k^{\prime}$ の值は再配列と塑性変形の寄与率 ${ }^{19)} の$ 影響を受

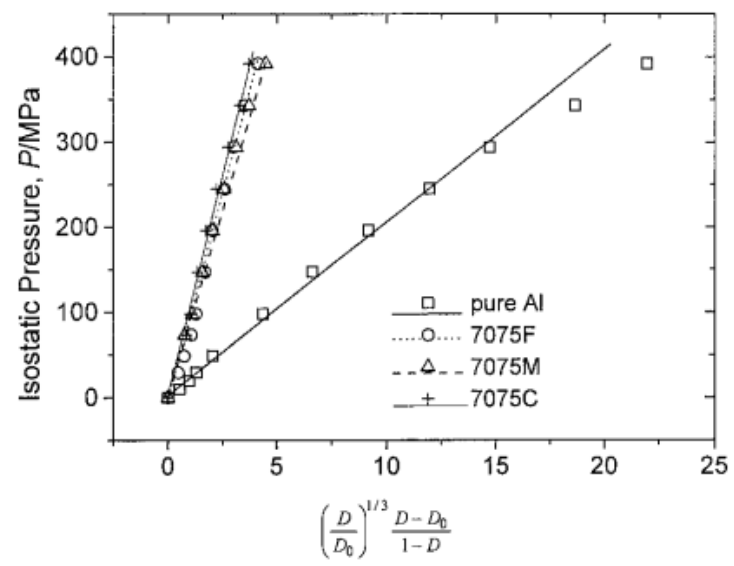

Fig. 10 The linear relation in equation (14-1) and experimental pressure for pure aluminum and aluminum alloy powders.

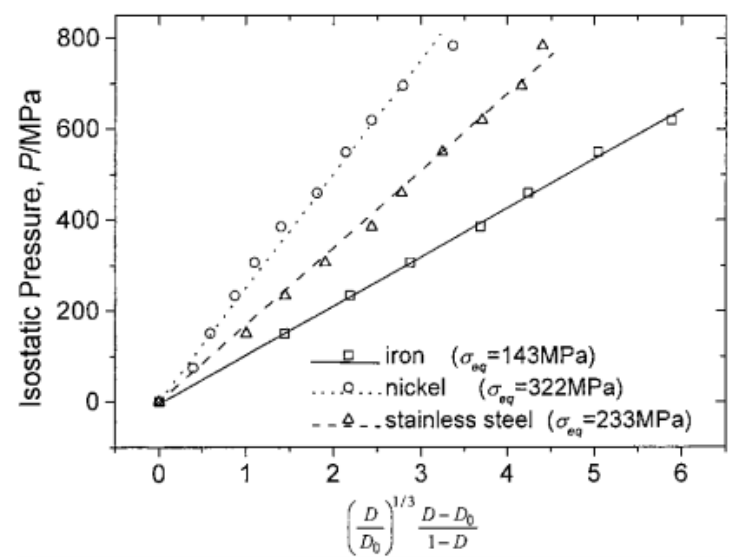

Fig. 11 The linear relation in equation (14-2) for the experimental results by James ${ }^{17)}$.

けているものと考えられる.

純アルミニウム粉と合金粉の実験結果と式 (14-1) との比 較を Fig. 10 に示す。この場合にも, 静水圧力は $\left(D / D_{0}\right)^{1 / 3}$ $\left(D-D_{0}\right) /(1-D)$ に対して良好な直線関係を示している. 7075 合金粉の勾配は明らかに純アルミニウム粉の場合の勾 配より大きい。これは式(14-1)に打ける相当応力 $\sigma_{\mathrm{eq}}$ の違い によるものである. Fig. 10 の勾配から $\sigma_{\mathrm{eq}}$ の值を求める と, 純アルミニウム粉の $\sigma_{\mathrm{eq}}$ として $23 \mathrm{MPa}$ が得られた.こ れは工業用純アルミニウムの $0.2 \%$ 耐力 $(1050: \geqq 20$ $\left.\mathrm{MPa}^{20)}\right)$ に近い值である。同様に 7075 合金粉の場合の $\sigma_{\mathrm{eq}}$ の值を求めると細粉で $134 \mathrm{MPa}$, 中粉で $120 \mathrm{MPa}$, 粗粉で $140 \mathrm{MPa}$ が得られた。これらの值は同じ粉末を放電焼結(黒 鉛型内単軸圧縮 : $873 \mathrm{~K}, 20 \mathrm{MPa}, 1200 \mathrm{~s}$ )した直後に型ごと 水焼き入れした材料 (相対密度 : 0.99 以上)の引張り試験結 果から求めた $0.2 \%$ 耐力 $120 \mathrm{MPa}$ に近い值である.

いくつかの文献データの静水圧下圧密における圧力 $P$ を 式(14-2)で整理して Fig. 11 と Table 3 に示す。これより従 来報告された実験データの $P$ も圧密時の粒子接触部の变形 応力 $\sigma_{\mathrm{eq}}$ を用いて，第 1 近似として式(14-2)で表される. 


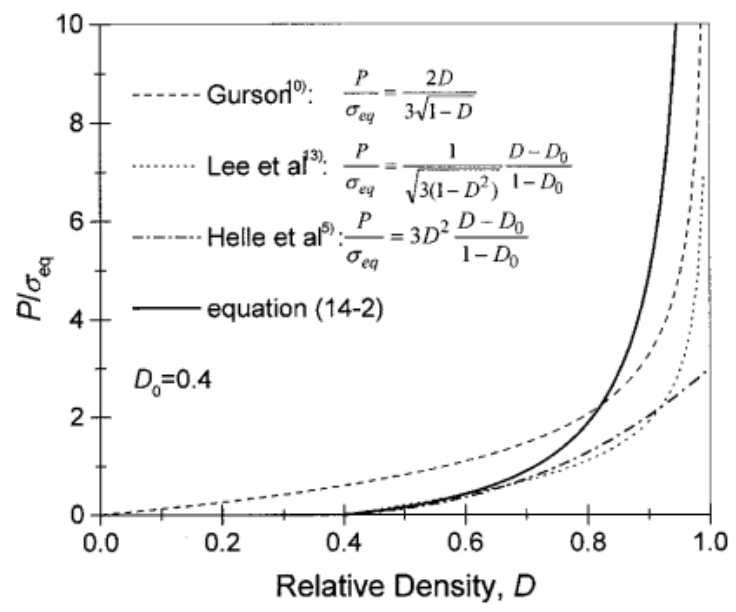

Fig. 12 Curves according to equation (14-2) and several equations in the previous reports.

\section{3 従来の構成式との比較}

圧粉体の Mises 型降伏理論によれば構成式は式 (18)の形 で表される。

$$
A(D) J_{2}^{\prime}+B(D) J_{1}^{2}=Y(D) \sigma_{\mathrm{eq}}^{2}=\Sigma_{\mathrm{eq}}^{2}
$$

ここで， $J_{2}^{\prime}$ と $J_{1}$ は巨視的主応力 $\Sigma_{1}, \Sigma_{2}, \Sigma_{3}$ を用いてそれぞ れ $(1 / 6)\left[\left(\Sigma_{1}-\Sigma_{2}\right)^{2}+\left(\Sigma_{2}-\Sigma_{3}\right)^{2}+\left(\Sigma_{3}-\Sigma_{1}\right)^{2}\right]$ および $\Sigma_{1}+\Sigma_{2}+$ $\Sigma_{3}$ で表される. $A(D), B(D)$ および $Y(D)$ は $D$ の関数で, それぞれ構成式のなかでの， $J_{2}^{\prime}, J_{1}^{2}$ および $\sigma_{\text {eq }}^{2}$ の寄与を表す 係数である. 静水圧下圧密の場合 $J_{2}^{\prime}$ は 0 であり, $P=\left(\Sigma_{1}+\right.$ $\left.\Sigma_{2}+\Sigma_{3}\right) / 3$ であるから, 圧力 $P$ は式 $(19)$ で表される.

$$
P=(1 / 3)[Y(D) / B(D)]^{1 / 2} \sigma_{\mathrm{eq}}
$$

従来の研究で報告されている $B(D)$ と $Y(D)$ を用いて $D_{0}=$ 0.4 の場合の比較を Fig. 12 に示す. ここで, Lee ら ${ }^{12)}$ の式 の $D_{0}$ は臨界相対密度 (タップ密度に近い值)である. 本図か らもわかるように, Helleの曲線以外は本実験結果と同じよ うに，相対密度が 1 に近づくと無限大になるような変化を している.すなわち, 本研究で提案された圧密式の大まかな 変化の傾向は Gurson ${ }^{10)}$ やLee らのそれに近いものである.

\section{5. 結言}

静水圧縮下の圧密構成式を考察し, 得られた結果と実験結 果を比較した．結論は次のように要約される.

実験的に求められた圧力 $P$-相対密度 $D$ の曲線は, $D$ が 1 に近づくと $P$ が非常に大きくなるような変化を示す．これ は実際には, 粉末粒子に対して圧密に寄与しない静水圧弾性 応力が増大するためと考えられるが，この効果を粉末のみか けの粒子接触面積 (拡張接触面積) が大きくなることで表すこ とによって, 次式で示される $P-D$ の関係が求められる.

$$
P=\left(3 k^{\prime} / 2\right) \sigma_{\mathrm{eq}} D_{0}\left(D / D_{0}\right)^{1 / 3}\left(D-D_{0}\right) /(1-D)
$$

ここで， $\sigma_{\mathrm{eq}}$ は相当応力で $0.2 \%$ 耐力に近い值であり, $D_{0}$ は 初期相対密度である. $k^{\prime}$ は粒子再配列の起こりやすさと, 再 配列に伴って変形がどの程度起こるかを表す定数で, 潤滑剂 を添加しない金属粉末の場合には $k^{\prime} D_{0}$ は 0.5 に近い值をと り，潤滑剤として液体パラフィンを $0.1 \%$ 添加した場合には 約 $0.3 \sim 0.4$ に低下する.すなわち，潤滑剤を添加しない金 属粉末の場合には上式は次式で近似される。潤滑剤を使用す ると, 圧力は本式で計算される值よりもいくらか小さくなる.

$$
P=(3 / 4) \sigma_{\text {eq }}\left(D / D_{0}\right)^{1 / 3}\left(D-D_{0}\right) /(1-D)
$$

本式による $P$ の $D$ にる変化は, 粒子接触理論による Helle の式よりもむしろ Gurson や Lee の式に近いものであ る.

本研究を行うに当たり，7075 合金および純アルミニウム 粉末を提供してくださった東洋アルミニウム秼，菊川氏に感 謝致します，また，圧密実験で多大な協力をしていただいた 広島県西部工業技術センタ一筒本氏，新田氏，広島市工業技 術センター隠岐氏に心から感謝致します。

\section{文献}

1) 例えば, K. Kawakita and K.-H. Lude: Powder Technol. 4(1970/71) 61-68.

2) H. F. Fishmeister, E. Arzt and L. R. Olsson: Powder Metallurgy. 21 (1978) 179-186.

3) H. F. Fishmeister and E. Arzt: Powder Metallurgy 26(1983) $82-88$.

4) E. Arzt: Acta Metal. 30(1982) 1883-1890.

5) A. S. Helle, K. E. Easterling and M. F. Ashby: Acta Metal. 33 (1985) 2163-2174.

6) P.-L. Larsson, S. Biwa and B. Strakers: Acta Mater. 44(1996) $3655-3666$.

7) L. Kuhn, J. Xu and R. McMeeking: Computational \& Numerical Techniques in Powder Metallurgy, ed. D. S. Madan, (TMS, 1992) 123-138.

8) S. D. Mesarovic and N. A. Fleck: Solid and Structures 37 (2000) 7071-7091.

9) S. Shima and M. Oyane: J. Mechanical Science. 18(1976) 285291.

10) A. L. Gurson: Trans ASME. 99(1977) 2-15.

11) S. M. Doraivelu, H. L. Gegel, J. S. Gunasekera, J. C. Malas, J. T. Morgan and J. F. Thomas Jr.: J. Mechanical Science 26 (1984) 527-535.

12) D. N. Lee and H. S. Kim: Powder Metallurgy 35(1992) 275279.

13) S. J. Park, H. N. Han, K. H. Oh and D. N. Lee: J. Mechanical Science 41 (1999) 121-141.

14) M. Koiwa: Bulletin Japan Inst. Metals 25 (1986) 640-648.

15) O. Molerus: Powder Technol. 12 (1975) 259-275.

16) L. J. Gibson and M. F. Ashby: Cellular solids, (Combridge University Press, 1998) 28.

17) P. J. James: Powder Metallurgy 7 (1977) 199-204.

18) K. Kondoh, R. Watanabe and H. Hashimoto: J. Japan Society of Powder and Powder Metallurgy 47 (2000) 853-859.

19) T. Itoh and Y. Wanibe: J. Japan Soc. Powder \& Powder Metallurgy. 46(1999) 16-21.

20) Japan Inst. Metals: Kinzoku Data Handbook, (Maruzen, 1993) 184. 